\begin{tabular}{|c|cc|}
\hline PORT SAID ENGINEERING JOURNAL & $\begin{array}{c}\text { Faculty of Engineering - Port Said University } \\
\text { No. 2 } \\
\text {-Architectural Engineering- }\end{array}$ \\
\hline
\end{tabular}

\title{
Managerial Smart Governance Model and Indicators as an Evaluation Methodology to Promote Public-Private Partnership in Infrastructure Projects
}

\author{
Ahmed m. Selim ${ }^{1}$
}

\begin{abstract}
Urbanization in recent decades faces great challenges, as a result of the rapid increase in population, whereas, The world's population will increase to be 9.2 billion in 2050, which means 2.2 billion more than now, therefore, that will affect directly in the country's infrastructure. Furthermore, the cost of the renewal and establishing new infrastructure will be too expensive and need huge budgets. This paper argues, smart governance through the context of cities infrastructure implementation, by activating citizens participation and using technology, in addition, the contribution of Public-Private Partnerships (PPPs) to provide smart solutions, funding, and improving the performance of operation and maintenance process for these projects, which considers the main pillar to face the urban growth challenges and achieving sustainable development. On another hand, and from analysis of the literature review for smart governance and (PPPs) approach, the study suggests a managerial governance model, which illustrate the role of the state, civil society, and the private sector, who play a critical role to achieve smart governance in infrastructure projects by (PPPs), to provide clear criteria to support the success of this type of projects, in addition, proposing indicators for smart governance in infrastructure projects to measure The extent of achieving effective participation between the parties to the suggested model.
\end{abstract}

Keywords: smart governance, public-private partnership, infrastructure projects, managerial model, smart governance indicators.

\section{INTRODUCTION}

Referring to the 2015 UN summit under title (Transforming our world: Sustainable Development plan 2030) recommendations, which adapted 17 goals [1], the newly agenda concentrates on issues related to sustainable urbanization within a specific goal as: (goal 11) "make cities and human settlements safe, inclusive, resilient and sustainable. As well, a number of other goals related to this issue, those on health (goal 3), education (Goal 4), water and sanitation (goal 6), energy (goal 7), Building resilient infrastructure, encouraging comprehensive and sustainable industrialization and promoting innovation (Goal 9), and strengthening implementation of the international partnership (Goal 17) are all related strongly to urbanization issues. Through the current urbanization trends, and from this point of view, sustainable development will not be achieved without sustainable urban development.

In this context, providing infrastructure through the approach of (PPPs) will be the main pillar to achieve sustainable development, from another hand, the

\footnotetext{
${ }^{1}$ Lecturer at Department of Architecture, Modern Academy for Engineering and Technology - Cairo - Egypt, Email: ahmed.selim@eng.modern-academy.edu.eg \& en_ams@hotmail.com
}

Received: 22-12-2020, Accepted: 25-02-2021

DOI : $\underline{\text { 10.21608/PSERJ.2021.54652.1082 }}$ enhancement of efficiency and quality of delivering city infrastructure and services entail large financial investments, therefore, the collaboration between the private, public sectors, and civil society become certain to finance the cost of this trend. As well as, the contribution of the Public-Private partnerships (PPPs) with the civil society will afford smart technology for the infrastructure by innovative solutions according to the available technology and recourses in the countries to accomplish social, environmental, and economic sustainability.

In fact, to achieve an effective partnership to build infrastructure and then strong (PPPs), and through previous experiences, smart governance through the context of infrastructure implementation for cites seems to be a vital solution to challenges carried by fast-growing urbanization, for instance, transportation, high cost of management, quality of life, and urban sprawl. So, wellbeing for the governance structures assists to build a successful distinctive city and avoid chaotic development.

\section{RESEARCH OBJECTIVES AND METHODOLOGY}

The research presents the objectives as the main objective and secondary objective, also the research methodology as a following: 


\subsection{Research Objectives}

The main objective of this study is to suggest Managerial Governance Model and the secondary one is proposing indicators for smart governance in infrastructure projects by public-private partnership (PPPs).

\subsection{Research Methodology}

The study focuses on three pillars, The first pillar is a literature review through: Identifying the urbanization and infrastructure challenges, analyzing infrastructure projects financing though (PPPs) concept, identifying urban governance, understanding smart governance in infrastructure projects to understand the vital role of it in (PPPs) projects, and how it affects its success, by using inductive method. The second pillar is an analysis of the literature review axis to deduct the managerial governance model and summarizing smart governance indicators by using the analytical method. The third pillar is the examination of the suggested model to evaluate the validity of it by using the summarized index through a case study (Marsa Alam Airport) and to assess the effectiveness and efficiency of the model in promoting infrastructure projects using the conductive method.

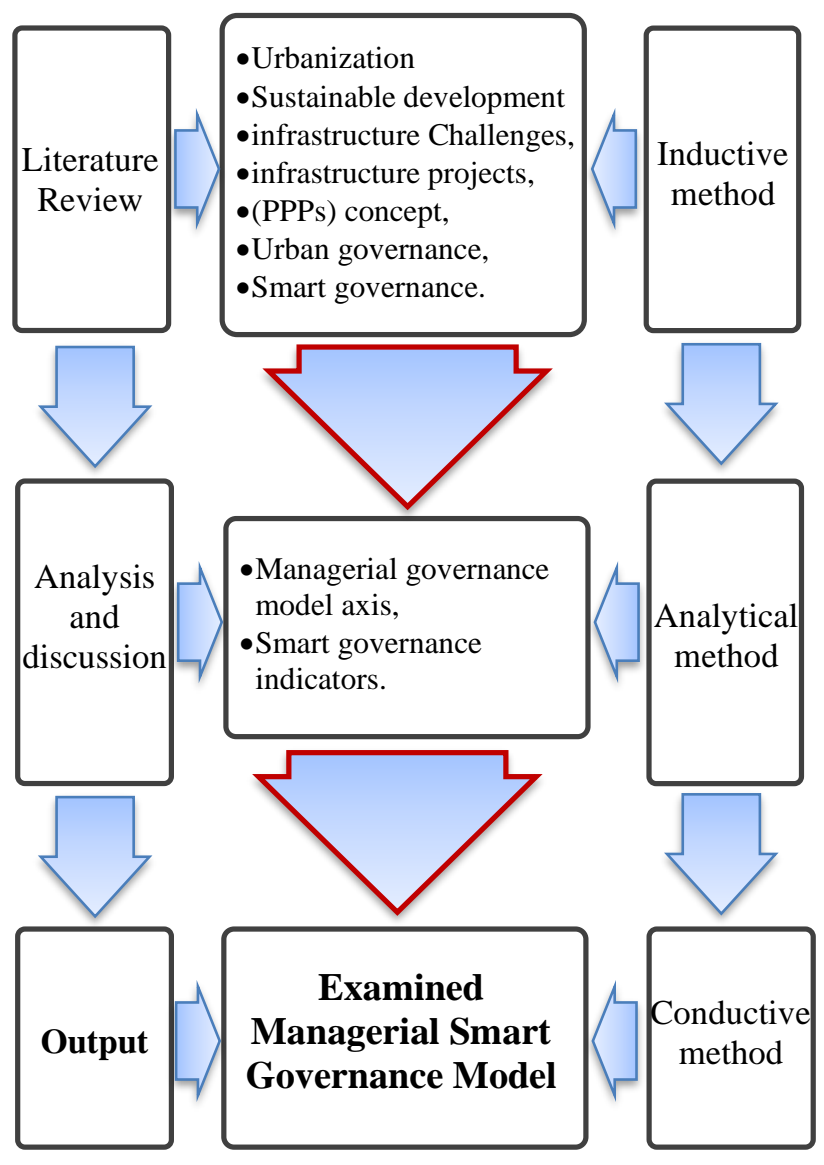

Figure 1: Research Methodology

\section{LITERATURE REVIEW}

\subsection{Sustainable Development}

After UN summit under title (Transforming our world: Sustainable Development plan 2030) in 2015, sustainable development becomes complex, due to it commits the governments to take all environmental, social, and economic aspects into consideration in decision-making processes. On another hand and as a result of the rapidly growing population, the urban areas become consuming natural resources while ignoring future needs, environmental and socio-economic problems. In this context, that creates intuitional challenges because it requires proactive government actions, smart policymaking, integrating between spatial plans and infrastructure development policies, and smart governance to implement sustainable development goals. As cities grow, their management becomes sensitive and crucial especially with sustainability goals, thus providing policies, institutional framework, smart technologies, and technical capacities will promote governments to achieve sustainability. From this point of view, urban sustainability, therefore, requires four pillars: social to achieve social justice by delivering the essential infrastructure for all citizens, economic to enhance efficiency, effectiveness, and productivity for urban infrastructure projects by accomplishing the maximum value for money (VFM), environmental to ensure the optimum use of natural resources, and urban governance to promote the participation of civil society and private sector in infrastructure projects.

\subsection{Sustainability and Urbanization Challenges}

The world's population will be 9.2 billion in 2050, which is 2.2 billion more than today, with most of the increase in Africa, the Middle East, and South Asia. The urbanization rate will reach 70 percent, which means an increase of 2.8 billion people in urban areas, compared to a decrease of 0.6 billion in rural areas. This is in addition to the nearly 4 billion people already living in urban areas, which requires building 400 new megacities in and around existing cities [2]. Thus, cities are always under pressure to deliver better quality services, encourage local economic competitiveness, enhance effectiveness and reduce costs, increase productivity, and treat congestion and environmental problems to achieve sustainability. These pressures are inspiring cities to spin to smart solutions and experiment with numerous infrastructure applications.

\subsubsection{Urban Infrastructure}

The link between infrastructure and economic growth is well established. Infrastructure has good impacts on poverty alleviation and development. Therefore, the infrastructure projects are considered the main pillar for accomplishing sustainable social, economic, and environmental development, and a key indicator of the progress of countries. Referring to the expectation of the world economic forum, the world will face a $\$ 15$ trillion 
infrastructure gap by 2040 [3]. So, it was imperative to research scientifically on how to meet this challenge.

\subsubsection{The Challenges of Urban Infrastructure}

Urban problems are multi-faceted and have a hard developmental challenge such as consumption and psychological needs of urban inhabitants in addition to institutional breakdowns, these problems pose severe economic, social, and environmental challenges to accomplish sustainable development in countries. The focal problem in countries is that the population growth rate is quicker than the rate of establishing and developing infrastructure and utilities. So, the investment in urban infrastructure facing a set of challenges, for instance: (1) accelerate the urban infrastructure planning documents and implementation to meet the expected population growth, (2) providing the financial resources required to execute adequate urban infrastructure with high quality, (3) urban governance and Governance of infrastructure, (4) use of traditional technologies for infrastructure maintenance through its life span.

\subsubsection{The Main Constraints of Infrastructure Projects Implementation}

When implementation infrastructure projects, particularly in developing countries, governments encounter many obstacles and challenges, the major points which reflect these challenges include: (1) identify the stakeholder's roles to avoid skills gap, (2) adapting (PPPs) approach to local circumstances, (3) applying smart governance models appropriately through achieving transparency of governmental systems, civil society participation in decision-making, and quality of political point of views [4], (4) lack in financing.

In fact, science, technology, and innovation (STI), and Information, communication and technologies (ICTs) concepts are considered the magic keys in overcoming these constraints by providing a digital platform from which to create an information network for the city's infrastructure [5], hence, the information will be afforded in the true-time and accurately, so that, cities will be ready to take action before the problem begins to ascend.

\subsection{Infrastructure Financing}

Financing the infrastructure projects has a unique nature as a result of their size; complexity and huge investment cost, thus, funding these projects need a large amount of money, sources of financing these projects for instance: (a) loans from local and international banks, (b) through tariff from the provided service, (c) from taxes, (d) by direct state funding, (e) by private sector institutions [6].

\subsubsection{Public-Private Partnership (PPPs)}

(PPPs) is considered one of the mechanisms that be used to encounter the financing challenges of infrastructure projects, also, it is one of the sustainable development goals SDGs for the united nation (goal 17). The (PPPs) consists of a group of stakeholders represented in the state and a private company where agrees to share both risks and rewards [7]. Throughout the last 25 years, more than 5000 infrastructure projects in 121middle and low incomecountries have been provided by (PPPs) through (BOT) concept, with investment financing $\$ 1.5$ trillion. To promote infrastructure such as railways, roads, airports, power plants, and water distribution networks [8].

The (BOT) concept is an application tool to achieve (PPPs) approach, UNCITRAL defines the BOT system as, "contractual arrangement between a public-sector agency and private sector concerns whereby resources and risks are shared for the delivery of a public service or development of public infrastructure". Several publicprivate partnership models are illustrated in Table (1).

Table 1: Public-Private Partnership Models

\begin{tabular}{l|l}
\hline Model & \multicolumn{1}{|c}{ Description of Model } \\
\hline BOT & Build, Operate and Transfer \\
BOT & Build, Own and Transfer \\
BOO & Build, Own and Operate \\
BOOT & Build, Own, Operate and Transfer \\
BLT & Build, Lease and Transfer \\
BRT & Build, Rent and Transfer \\
BT & Build and Transfer \\
BTO & Build, Transfer and Operate \\
BOR & Build, Operate and Renewal of concession \\
\hline DBO & Design, Build, Operate \\
DBOM & Design, Build, Operate and Maintain \\
DBMF & Design, Build, Manage and Finance \\
DBFO/ & Design, Build, Finance and Operate/Maintain \\
M & Modernize, Own or Operate and Transfer \\
\hline MOT & Rehabilitate, Own and Operate \\
ROO & Rehabilitate, Own and Transfer \\
ROT & Operate and Maintain \\
O\&M &
\end{tabular}

Source: Author based on [9]

\subsection{2. (PPPs) Mutual Characteristics and Features}

(PPPs) have the following mutual characteristics [10]: (1) normally based on a long- term contracts to enable innovation and reducing the project life cycle costs (2) both partners shares risks and rewards, (3) both partners seeking to better utilization of the local available resources, (4) private sector usually provide design, financing, maintenance, and operation, (5) both partners try to get win-win balance.

\subsubsection{Advantages of (PPPs) Approach}

The advantages of partnership whatever the type of contract can be listed as: (a) the assets remain- state owned, (b) risk and rewards distributed fairly,(c) decreasing the corruption, (d) develop local and international market, (e) increasing jobs and reducing unemployment, (f) encourage competitiveness, (g) improve the efficiency of maintenance and operation for the asset, (h) technology transfer [11]. 


\subsubsection{Smart $\left(\mathbf{P P P}_{\mathrm{s}}\right)$ for Funding Infrastructure Projects}

Despite the diversity of city patterns, they confront frequent challenges to accomplish infrastructure projects as mentioned above, funding is considered the main obstacle to implement these projects. In fact, the smart (PPPs) approach is a new trend for implementing infrastructure projects especially with the merge of (STI) and (ICTs) concepts, hence it became totally different from the traditional one for several conditions which can be discussed as [12][13]: Smart (PPPs) projects are depending on technology and innovative solutions, it can be funded and implemented by medium-sized local or international firms compared with the traditional one which needs huge funding, services, and supplements providers, therefore, it is flexible if compared with traditional rigid (PPPs) because it is based on (STI) concept and directly linked with users and approved by the civil society.

\subsection{Urban Governance}

Governance has been a magic key approach in urban studies problems treatment since late 1980 [14]. It discusses how government (local, regional, and national) and stakeholders can plan, finance, and manage urban areas. It includes a continuous procedure of negotiation and disagreement through the distribution of social and material resources and political power [15], a wide range of academic reviews define the governance from a different point of views, the research adopted two defamations for the governance, the first one: governance can be recognized as an interplay of institutional, units, sectors, and process, and the second one: governance is an arrangement of governing outside the state but with obvious inclusion of parts of the state institutions structured as horizontal networks to associate, support, monitor and control the private sector (the market), civil society ( usually NGOs), and state actors [16]. From a comprehensive perspective, governance is an interactive relationship between stakeholders represented in (The State) to create a favourable political, legal, and economic environment, private sector (The Market) to provide the funding and opportunities for investment, and Civil Society to mobilize citizens' participation, within the work and collective arrangement to protect the legal rights and duties of citizens and mediate their differences.

\subsubsection{Good Governance}

The term "good governance" was first mentioned, in the World Bank's report in 1992 it means: "it entails requires sound management of public sector (efficiency, effectiveness, and economy), accountability, exchange and free flow of information (transparency) and the legal framework for development (fairness, respect human rights and freedoms)." [17], based on this definition, there are (eight) characteristics for good governance: a. Accountability, b. Transparency, c. Responsiveness, d.
Effectiveness and efficiency e. Rule of law, f. Participation, g. Equity and inclusiveness, h. Consensus Orientation. Therefore, these characteristics will enforce:

- Political, legal, and social accountability,

- Free flow and access to information,

- Optimal use of resources,

- A fair legal framework,

- Civil society(NGOs) sharing in decision making,

- Monitoring of government institutions and activities.

\subsubsection{Strategies for Good Governance in (PPPs) Projects}

Making changes in governance and launching new projects is extremely difficult. However, by engaging citizens from the beginning, it is easier for officials to develop cooperation and discover frustrations that the public feels about local governance, rely on new technology, communicate with stakeholders, monitor progress, and the introduction of new policies can be made smoother [18]. From this point of view, the development of good governance strategies requires:

- Reorienting the nation's priorities through appropriate investment,

- Enabling state institutions,

- Strengthening the parliament role and increasing its effectiveness,

- Promoting the capacity of the civil society to achieve accountability,

- Creating new alliances with civil society,

- Developing new mechanisms for the cooperation between the state and the private sector.

\subsubsection{Smart Governance for Cities}

Ultimately smart government relies on a smart governance model, which requires revised public budgeting standards, policies geared towards sustainability and flexibility, successful smart practices, information sharing, information and communication technologies, and frequent updating of skills and human capital [19]. Smart governance further include:

- Smart regulation, which embraces and promotes accountability, transparency, and fairness,

- cooperation of the various levels of government commercial institutions and non-government organizations,

- Information sharing, and stakeholder involvement in the decision-making process,

- Achieving balance for potential tensions between urban sustainability, and economic attractiveness and competitiveness,

- The focus on assessing the feasibility of the project was essential when developing the infrastructure for smart governance,

- Facilitating Citizens' interaction with the government,

- Solve various problems and improve people's life, 
- Narrowing the gap between public and private sectors, and promoting smart industries, leading to a revitalized economy [20].

\subsubsection{The Pillars of Smart Governance to achieve Sustainability}

Referring to the adopted smart governance definitions in the research, and as regards the role of it in achieving sustainable development, it can be concluded the main pillars for it as:

\subsubsection{Governmental Organization}

The governmental organization is considered the first pillar of smart governance, this term consists of a range of features, for example, vision, strategies, motivation, decision-making, process coordination, roles, responsibilities, in addition to, providing regulation, funding, technology, human resources, and knowledge management. There are three significant characteristics for the organization to ensure that smart governance is achieved as: (1) responsiveness, (2) commitment, and (3) operational management.

\subsubsection{Citizen Participation}

Citizen participation is not only the second pillar but also the most important one, citizens must share in decisionmaking with the government through effective suggestions and plans to arrive at better-informed policy decisions. There are three features for this pillar as: (1) the interaction between citizens and government in urban governance, (2) the percentage of the participating population, (3) providing motives for community participation.

\subsubsection{Use of Technology}

The third pillar of smart governance is the use of technology, especially information, communication, and technology (ITCs), within how digital technology are applied in achieving a free flow and access to information, thus, sharing decision-making in the participatory governance process which aims to realize sustainable urban development, on the other hand, the

types of technologies used have tremendous effectiveness in achieving transparency and successful operational management [21].

\subsubsection{Use of Environmental Protection Tools}

The fourth pillar is environmental protection, in fact, many countries face a great challenge in integrating spatial planning with long-term environmental sustainability, due to the weakness of the regulations and government policies. Therefore, environmental management system (EMS) and environmental impact assessment (EIA) are considered important tools to support the governmental organizations in evaluating the current situation of the environment and determining a protection plan and regulations for it as well, achieving the optimum use of natural resources for infrastructure projects to promote smart governance and environmental sustainability.

\subsubsection{Infrastructure projects by Smart $\left(\mathbf{P P P}_{\mathrm{s}}\right)$ and Smart Governance}

Urban infrastructure projects by (PPPs) are complicated systems that are with very long lifecycles, complex contract relations, many stockholders with skill gaps, and time-consuming to develop and deliver [22]. If infrastructure projects are designed, operated, maintained correctly, that will lead to saving cost in services delivery, therefore, decrease the tariff and can have invaluable impacts on the well-being and growth of communities [23]. On the other hand, any potential failure may have occurred during these types of projects, the result will be catastrophic because that will consider waste of resources, opportunities, and money [24]. From this point of view, smart governance and its pillars play a fundamental role in leading such projects toward success as illustrated in Table (2).

Table 2: Urban Governance and Smart Governance

\begin{tabular}{l|l|l}
\hline & \multicolumn{1}{|c}{ Trban Governance } & \multicolumn{1}{c}{ Tradional (PPPs) }
\end{tabular}




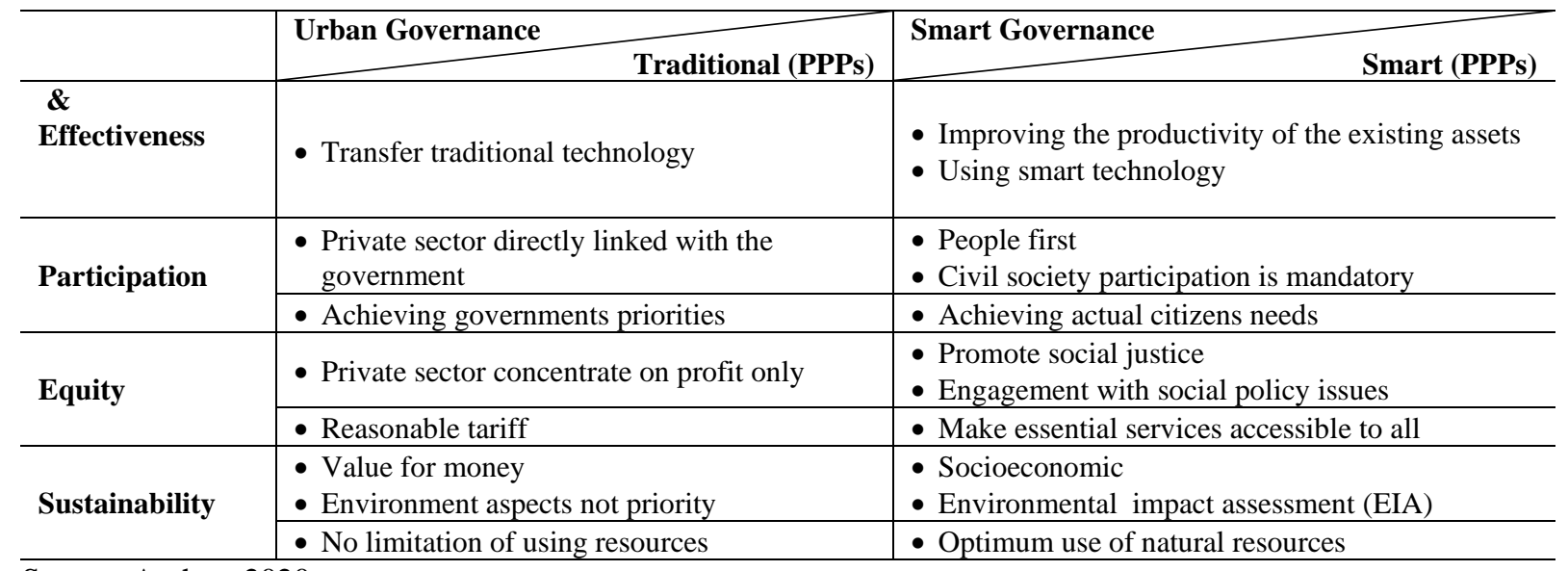

Source: Author, 2020

\section{RESULT}

\subsection{Smart Governance Indicators}

Through literature review and previous studies about studying and analysing good governance, smart governance, and its features, the research concludes indicators which are considered essential for promoting smart governance, also, to measure the extent to which these approaches are achieved (PPPs) in cities. These indicators can be identified in the following (Table 3).

Table 3: Smart Governance Indicators.

\begin{tabular}{|c|c|}
\hline Indicators & Outcomes \\
\hline $\begin{array}{l}\text { Citizens' interaction with the } \\
\text { government }\end{array}$ & $\begin{array}{l}\text { - Determine actual needs and priorities, } \\
\text { - Understanding citizens' problems and context, } \\
\text { - Promote accountability, } \\
\text { - Sharing risks. }\end{array}$ \\
\hline $\begin{array}{l}\text { Providing and sharing } \\
\text { information }\end{array}$ & $\begin{array}{l}\text { - Promote transparency, } \\
\text { - Equality of participation, } \\
\text { - Motives for citizens to participate. }\end{array}$ \\
\hline $\begin{array}{l}\text { Innovation (ICT), Easy } \\
\text { access to information }\end{array}$ & $\begin{array}{l}\text { - Reorienting priorities of the government through suitable investment, } \\
\text { - Increasing efficiency and effectiveness in government Processes. } \\
\text { - Successful smart practices. }\end{array}$ \\
\hline $\begin{array}{l}\text { Transparency in government } \\
\text { processes }\end{array}$ & $\begin{array}{l}\text { - Trust in government, } \\
\text { - Citizen satisfaction, } \\
\text { - Reducing corruption. } \\
\end{array}$ \\
\hline Smart regulation & $\begin{array}{l}\text { - the rollout of policies can be made smoother, } \\
\text { - reducing investment risks, } \\
\text { - link and integrate the different systems, } \\
\text { - Direct communication channels between government and citizens }\end{array}$ \\
\hline Optimum use of resources & $\begin{array}{l}\text { - meeting the needs of present and future generations, } \\
\text { - reducing investment cost, } \\
\text { - Enhancing the environment. }\end{array}$ \\
\hline Private Sector Participation & $\begin{array}{l}\text { - Solving various problems and improving people's life, } \\
\text { - Providing an alternative source for funding, } \\
\text { - Improve operation and maintenance process } \\
\text { - Decrease unemployment, } \\
\text { - Smart Technology exchange and transfer. }\end{array}$ \\
\hline $\begin{array}{l}\text { Civil society (usually NGO) } \\
\text { participation }\end{array}$ & $\begin{array}{l}\text { - Enhanced legitimacy of local government, } \\
\text { - protect citizens legal right, } \\
\text { - Increased collaborative ability, } \\
\text { - Public engagement, } \\
\text { - Strengthening state institutions. }\end{array}$ \\
\hline
\end{tabular}

Source: Author based on [19], [20], [21] 


\section{5. (PPPs) Managerial Smart Governance Model}

Smart governance plays a fundamental role in improving government systems, involving various stakeholders, offering equal citizen engagement opportunities, transparent information-sharing mechanisms, and other benefits. In fact, the state, civil society, and the private sector as illustrated in (Figures $\mathbf{2 8 3}$ ) play a critical role to achieve smart governance in infrastructure projects by (PPPs). Therefore, determining the role for each one in a frame of the Managerial smart governance model, that will provide clear criteria to support the success of this type of projects.

The managerial smart governance model main objectives are providing infrastructure and achieving sustainable development pillars through determining the actual needs to reinforce achieving the value for money (VFM) which reflect the economic pillar, providing services for all citizen which reflect the social pillar, and provide funding by private sector to implement projects achieving protection for the environment which reflect the environmental pillar, as well as:

- Producing and delivering public services for all,

- Improving the efficiency of service delivery and production,

- Supporting experience and technology transfer to the public sector,

- Emphasis science, technology, and innovation (STI) as the main approach to achieve smart (PPPs),

- Promoting people and civil society participation.

\subsubsection{State Role in the Managerial Governance Model}

State role in the managerial governance model is divided into two dimensions, the first one is the legal framework and regulations to provide protection and privacy for the data flow and access, protecting the intellectual property of the smart technology, and introducing legal clauses on updates to technological changes. The second dimension is Ex-ante evaluation by preparing General Researches prior to project elaboration to determine customer needs and focusing on priorities, benchmarking studies, analysis of the local capacities and administrative capacities by feasibility studies to determine the best modalities of the PPP project within financial analysis: affordability, bankability, value for money analysis, risk assessment and impact analysis, and determining the expected project milestone dates starting from tender date to the completion date, therefore, facilitating dispute resolution procedures between the parties during the agreement, achieving a balance between the parties at those dates, and Managing the agreement contracts in a sustainable scientific framework.

\subsubsection{Civil society role in the managerial governance model}

Civil society role in the managerial governance model is Making (PPPs) fit for purpose and monitoring the project phases within the principle of "people first" by (NGOs). In addition, the research and consultation centers in the universities are considered effective civil society actors that support scientific research and innovation by providing new smart technologies approach for the private sector to promote infrastructure projects, therefore, increasing efficiency and improving productivity for it. Whereas, it can be accomplished through:

- Increase access to essential services to people especially in poor urban areas,

- Providing essential services for all people without constraints, thus promoting social justice,

- Increase efficiency "doing more with less",

- Improving the productivity of existing assets and making savings,

- Improving the (quality of life) by the smart (PPP) tools, which means the aim is not to deliver the basic needs but to improve the efficiency of the services to achieve comprehensive sustainable development,

- The technology is normally invisible, and most of the smart (PPPs) projects depend on the technology, therefore, peoples and civil society participation is too important to evaluate these types of services,

- Enabling the local government to be at the same level as the private sector in terms of power and rights to achieve a balanced relationship between the two parties 'win-win' situation.

- Monitoring and evaluating the agreement during the milestone dates.

\subsubsection{The private sector role in the managerial governance model}

Private sector role in the managerial governance model is accelerating development in infrastructure projects through:

- Provide strategies to meet the needs of present and future generations.

- Providing smart technology.

- Reducing investment cost.

- Achieving a 'win-win' situation with the public sector.

- Sharing project risks with the public sector.

- Increase job opportunities.

- Enhancing the environment. 


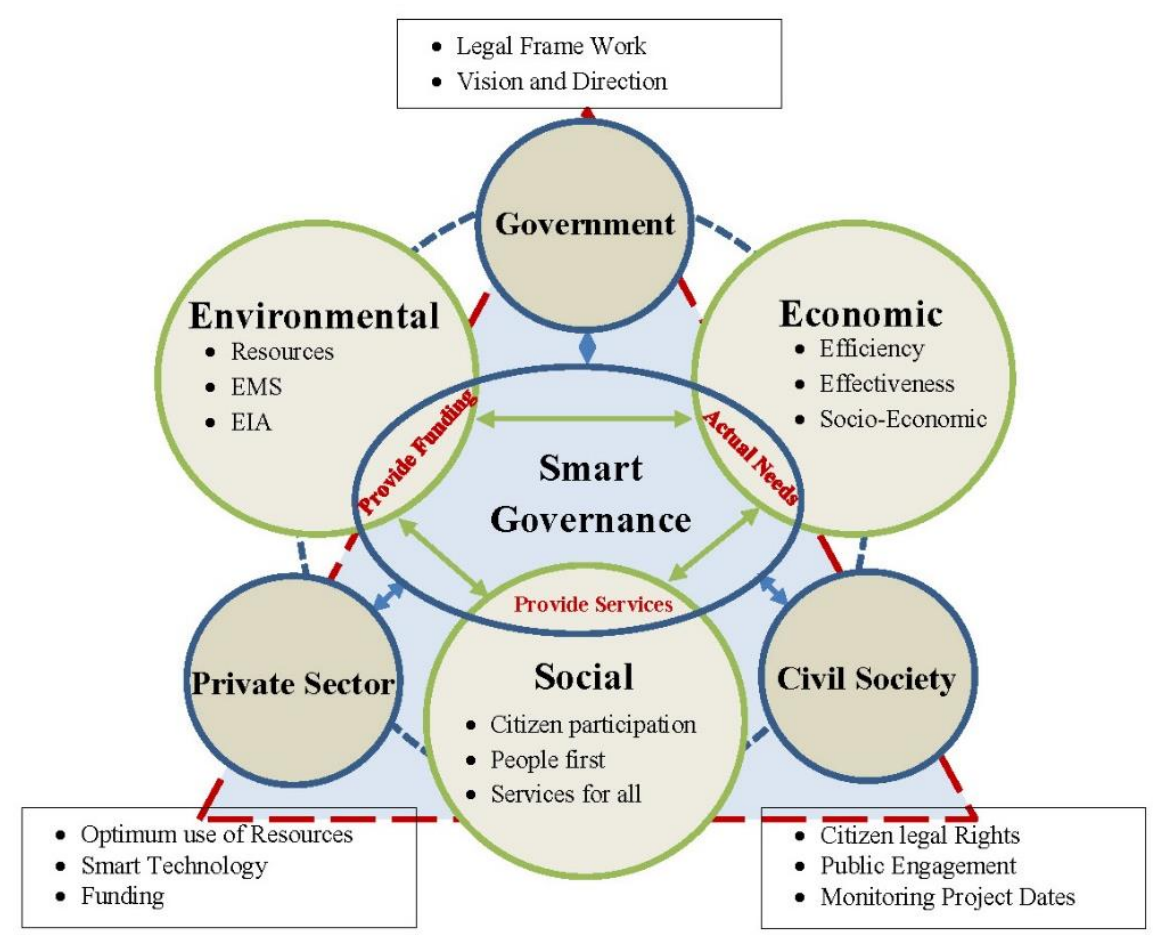

Figure 2: PPPs Smart Governance Conceptual Model (Source: Author, 2020)

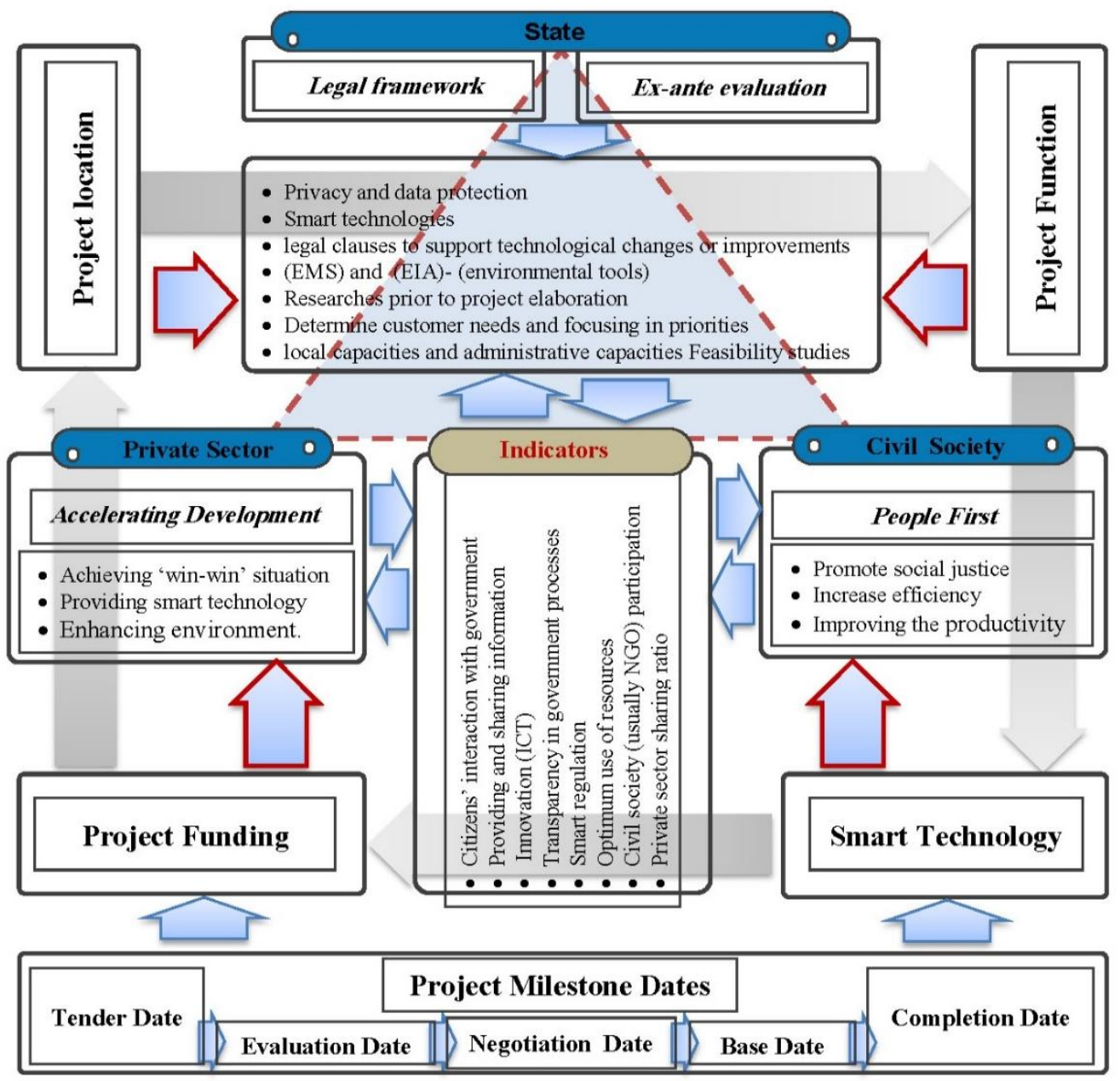

Figure 3: PPPs Managerial Smart Governance Model (Source: Author, 2020) 


\section{ANALYSIS AND DISCUSSION}

\subsection{Managerial Smart Governance Model Effectiveness and Efficiency}

This part of the research deals with examining the proposed managerial model through applying it to the Marsa Alam Airport implementation agreement to measure its effectiveness and efficiency within the model pivots and indicators.

\subsubsection{Marsa Alam Airport Implementation Agreement (Case Study)}

Marsa Alam Airport implementation agreement is one of (PPPs) models for partnership contracts in infrastructure projects / basic services that have been carried out with Egypt government and the private sector with the (BOT) system as illustrated in (Table 4), the state has turned to this pattern due to the increase in Hurghada airport traffic demand whether for passengers or cargo, as the total volume of passengers increased by $106 \%$ over the capacity of this airport in the period from 1995 to 2000, also as a result of the high investment costs required to establish this airport, this had a great impact on the state's encouragement of partnership with The private sector is about to participate in the development of the airport sector.

State role in the agreement is providing the project land, identifying customer needs and priorities, addressing the legal framework and regulations, determining the expected milestone dates and project budget.

Private Sector role in the agreement is funding and implementing the project, sharing project risks with the public sector, providing technology and maintenance.

Civil Society role in this agreement was too weak, due to the participation of (NGO) role during the tender time was not identified in the law.

Table 4: Egypt's experience in partnership projects with the private sector - the airport sector.

\begin{tabular}{|c|c|c|}
\hline \multicolumn{3}{|c|}{ Marsa Alam Airport (PPPs ) Agreement } \\
\hline Agreement Type & \multicolumn{2}{|l|}{ Built - operate - transfer ( BOT) } \\
\hline Capital Investment & \multicolumn{2}{|c|}{200 million\$ increased to 1.2 billion $\$$} \\
\hline Partners & \multicolumn{2}{|c|}{ El korafy ( private sector ) \& Imac Marsa Alam ( Public sector ) } \\
\hline Legal Framework & \multicolumn{2}{|c|}{ Law No. 3 of 1997 and Law No. 119 of 1983} \\
\hline Agreement Period & \multicolumn{2}{|l|}{40 years - Expire Date in 2038} \\
\hline \multirow{2}{*}{ Milestone Dates } & 1-Tender Date (FEB-1998) & 3-Effective Date (JAN- 1999) \\
\hline & 2-Evaluation Date (DEC- 1998) & 4-Expiry Date (FEB- 2038) \\
\hline
\end{tabular}

Source: Author, 2020

\subsubsection{Marsa Alam Airport Agreement (Analysis and Evaluation)}

The Marsa Alam Airport agreement is considered one of the most successful experiences of the partnership between the public and private sectors in Egypt, despite the negatives that will be addressed below.

By analysing this agreement, we find the following:

- The project company shall pay to the owner a share of $5 \%$ of the revenue,

- The administrative body cannot amend the terms of the agreement during its implementation or withdraw the project from the project company,

- No ceiling has been set for the investor's profits,

- All equipment and services, which needed to operate the airports are Exempted from all types of taxes.

Through the examination of the proposed managerial model and its pivots on the agreement according to (Table 5), and by analysing the results as illustrated in (Figure 4) where the agreement fulfills $31 \%$ of the requirements of the managerial model, does not fulfill $42 \%$ of its requirements, and fulfills $27 \%$ of its requirements partially as well. Consequently, the model is valid to be used in evaluating infrastructure projects by (PPPs). By Examining this agreement, we find The positives as: (a) The procedures for selecting the project company to implement, operate and maintain the project were transparent, by depending on the competitive bidding method, (b) Helped to encourage the tourist movement, especially in the Marsa Alam area, (c) The project has created nearly 5,000 job opportunities and The negatives of the agreement as: (a) The tender documents include a fixed revenue percentage to be paid to the government representative (b) The government did not take into account the natural conditions nor the provision of infrastructure services for the Airport area, (c) No maximum limit has been set for the investor's profit from the offered capital, therefore, The balance between the public and private interest has not been achieved. 
Table 5: Managerial Model Role Examination

\begin{tabular}{|c|c|c|c|c|}
\hline Role & F.F & P.F & N.F & Indictors (Measurement index) \\
\hline State Role & & & & \\
\hline - Privacy and data protection & & & & \multirow{8}{*}{$\begin{array}{l}\text { - Providing and sharing information } \\
\text { - Easy access to information } \\
\text { - Transparency in government processes } \\
\text { - Optimum use of resources } \\
\text { - Smart regulation }\end{array}$} \\
\hline - Smart technologies & & & & \\
\hline - support technological changes & & & & \\
\hline - Researches prior to project elaboration & & & & \\
\hline - focusing on priorities & & & & \\
\hline - Determine customer needs & & & & \\
\hline - local capacities Feasibility studies & & & & \\
\hline - administrative capacities Feasibility studies & & & & \\
\hline
\end{tabular}

(3) of (8) roles achieved (F.F) which represent 37.5\%, (2) of (8) roles achieved (P.F) which represent 25\%, and (3) of (8) roles achieved (N.F) which represent $37.50 \%$

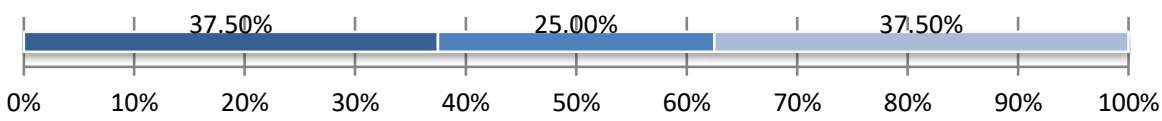

\begin{tabular}{|c|c|}
\hline \multicolumn{2}{|l|}{ Civil Society Role } \\
\hline - Promote social justice & \multirow{7}{*}{$\begin{array}{l}\text { - Citizens' interaction with the government } \\
\text { - Providing and sharing information } \\
\text { - Transparency in government processes } \\
\text { - Civil society participation }\end{array}$} \\
\hline - Increase efficiency & \\
\hline - Improving productivity & \\
\hline - Enhance the legitimacy of local government & \\
\hline - protect citizens legal right & \\
\hline - Increased collaborative ability & \\
\hline - Public engagement & \\
\hline
\end{tabular}

(1) of (7) roles achieved (F.F) which represent 14.28\%, (3) of (7) roles achieved (P.F) which represent 42.86\%, and

(3) of (7) roles achieved (N.F) which represent $42.86 \%$.

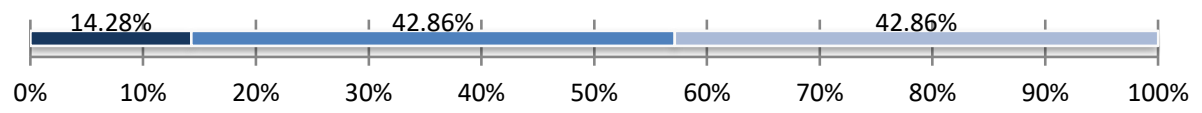

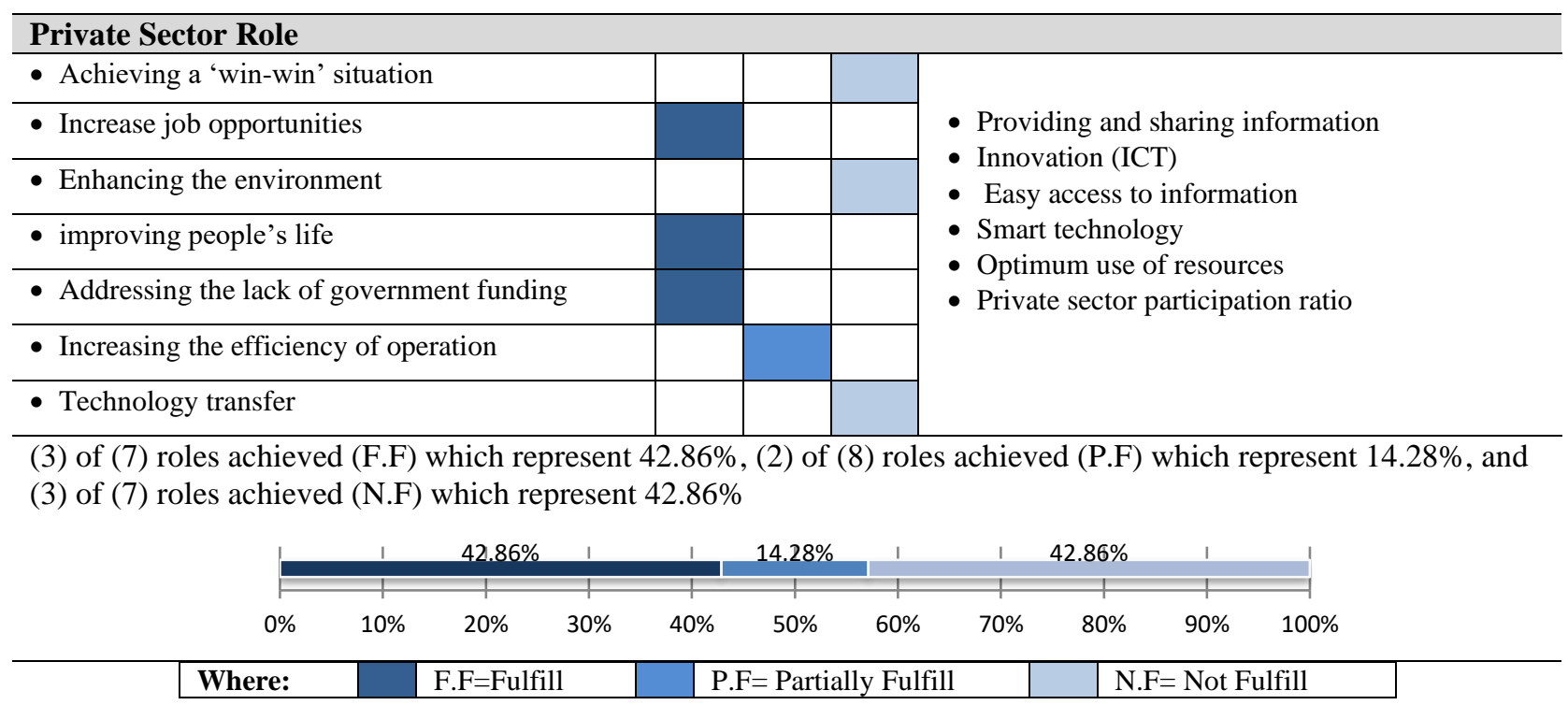

Source: Author, 2020 


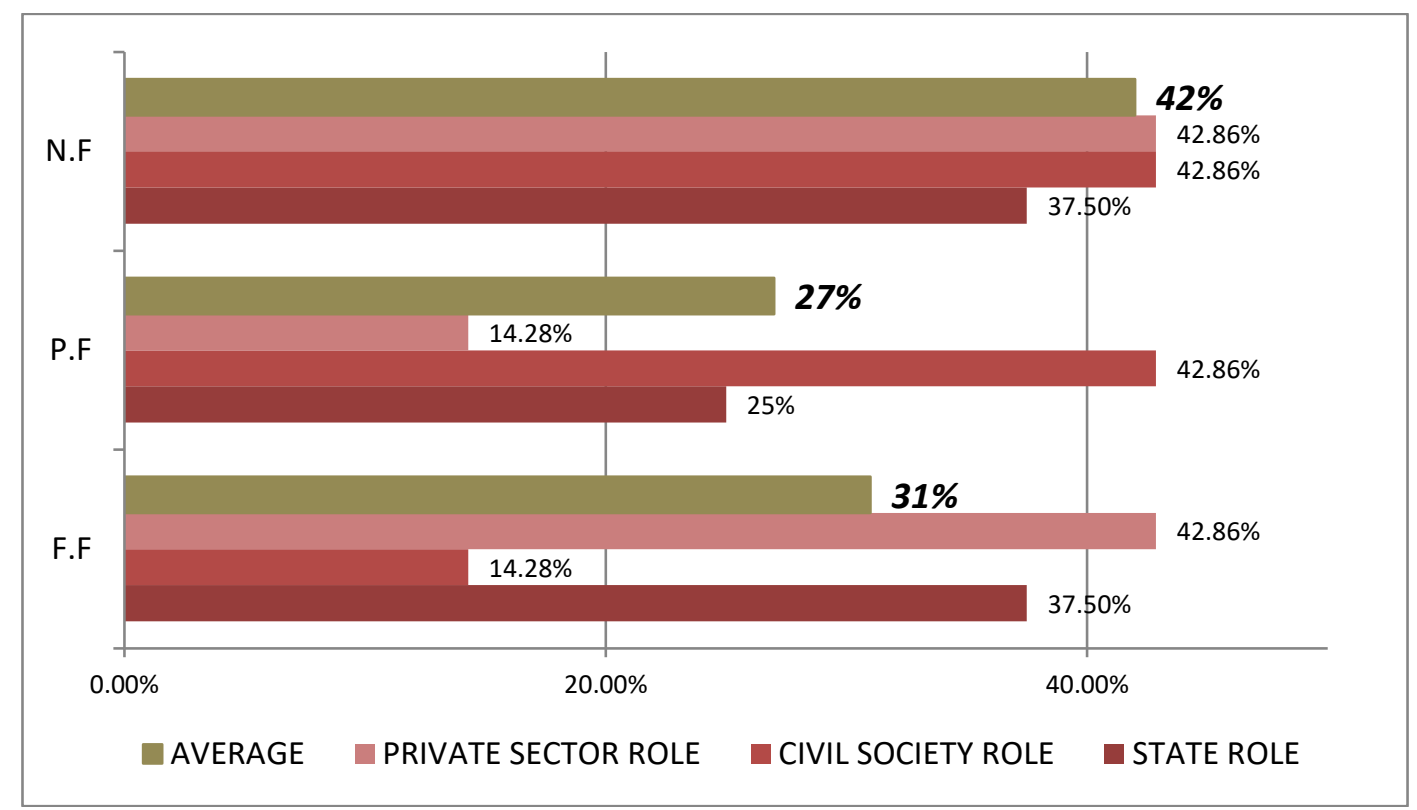

Figure 4: Managerial Smart Governance Model Role Examination (Source: Author, 2020).

\section{CONCLUSION}

Applying smart governance in infrastructure projects by (PPPs) will improve the (quality of life) by the smart (PPPs) tools. Thus, facing the urbanization challenges through, citizen participation and using technology. On another hand, suggesting the managerial smart governance Model and smart governance indicators for these types of projects will provide a 'win-win' situation among the private sector and government. Through the presented research, the most important results and recommendations can be summarized as follows.

\section{RESULTS}

The research results could be summarized as:

a- Results related to smart governance and infrastructure projects:

- Applying smart governance approach will accelerate the urban infrastructure planning documents and implementation to meet the expected population growth,

- It will play an essential role in improving government systems, involving various stakeholders, offering equal citizen engagement opportunities, transparent information-sharing mechanisms, and other benefits,

- Promoting the achievement of sustainable developments in infrastructure projects, through the optimum use of resources, involving environmental protection into consideration to promote environmental sustainability,

- Supporting civil society participation in decisionmaking to improve the quality of political point of views through sharing in determining the actual needs and priorities,
- Achieving optimum use of the interrelated information, by information and communication technologies or (ICTs) approach as a critical role in enhancing the physical and digital infrastructure as well.

$b$ - Results related to (PPPs) in infrastructure projects:

- Enabling All the stakeholders in decision making and responsibility, and achieving Fair distribution of risks and rewards,

- Accomplishing healthy competition and free flow and access to information, therefore promoting transparency,

- Providing the financial resources required to execute adequate urban infrastructure with high quality,

- Make science, technology, and innovation (STI) is the main approach to achieve smart (PPPs) by providing smart technologies, as well value for money (VFM) as in the traditional (PPP),

- Promoting sustainability through accomplishing efficiency, effectiveness, productivity (economic pillar), social justice, make essential services accessible to all, (social pillar), and Optimum use of natural resources, environmental protection procedures (environmental pillar),

$c$ - Results related to the suggested (PPPS) managerial smart governance model:

- The suggested managerial smart governance model can support in Strengthening state institutions, evolving a new framework for the government and private sector, and determining the role of the state, private sector, and civil society which will provide clear criteria to support the success of this type of projects,

- Using smart technology and innovative solutions, 
- The suggested indicators could measure and enhancing Trust in government, reducing corruption, and achieving effective Private sector participation,

- Determining the expected project milestone to avoid any conflict between the stakeholder's decisions and achieving successful monitoring for the project phases by the civil society.

$d$ - Results related to the examination of the suggested model to the case study (Marsa Alam Airport Agreement):

- The proposed model and indicators are valid to evaluate and measure the effectiveness of applying smart governance approach in (PPPs) infrastructure projects and providing the tools to transform it to be smart.

\section{RECOMMENDATIONS}

- There is a need to promote the link between smart urban governance and sustainable developments, by providing regulations, governmental institutions, and awareness for optimum use of resources,

- Give priority to developing standardized legal and regulatory practices to accelerate PPP especially in the developing countries,

- Public sector and civil society must be partners in (PPPs) smart projects through sharing risks, responsibilities, and rewards,

- More research are needed to accomplish more equitable and effective service delivery, increasing accountability, enhancing the legitimacy of local government, and Improving policy design and implementation.

\section{References}

[1] United Nations (2015), "Transforming our world: the 2030 Agenda for Sustainable Development", pp.14 [online],https://www.un.org/ga/search/view doc.asp?symb ol=A/RES/70/1\&Lang=E (Accessed 20 September 2020).

[2] United Nations: Department of Economic and Social Affairs (2015), "PROTOTYPE GLOBAL SUSTAINABLE DEVELOPMENT REPORT”, UN conference on sustainable development, New York 2014 ,

pp.64[online],https://sustainabledevelopment.un.org/conte nt/documents/1454Prototype\%20Global\%20SD\%20Report 2.pdf (Accessed 15 September 2020).

[3] World economic forum. (2019, April), Retrieved March 21, 2020, from https://www.weforum.org/agenda/2019/04/infrastruct ure-gap-heres-how-to-solve-it/

[4] Giffinger, R., Fertner, C., Kramar, H., Kalasek, R., Pichler-Milanovic, N. and Meijers, E. (2007) Smart Cities - Ranking of European medium-sized cities, Vienna University of Technology [online], http://curis.ku.dk/ws/files/37640170/smart_cities_fin al_report.pdf (Accessed 20 March 2020)
[5] Rudra P. P., Girijasankar M., Tapan P. B. (2018), "Information communication technology (ICT) Infrastructure and economic growth: A Causality evinced by cross-country panel data", IIMB Management Review, VOL 30, Issue 1, PP 91-103, [Online] https://www.sciencedirect.com/science/article/pii/s 0970389618300260, (Accessed March 2020).

[6] Tagen,R. (2007). "Partnership contracts by ppp ", Dar el nahda elmasryia, Cairo.

[7] Sabol, P. and Puentes, R. (2014). "Private Capital, Public Good: Drivers of Successful Infrastructure Public-Private Partnerships". Washington D.C. [Online]

https://www.brookings.edu/wpcontent/uploads/2016/ 07/BMPP_PrivateCapitalPublicGood.pdf (Accessed 28 March 2020).

[8] World Bank (2017), "Benchmarking Public-Private Partnerships Procurement 2017: Assessing Government Capability to Prepare, Procure, and Manage PPPs”, pp.14, Washington, DC. [Online] http://documents.worldbank.org/curated/en/46396147 6780341706/pdf/109245-WP-PPPBenchmarkingPUBLIC.pdf (Accessed 28 March 2020).

[9] Nassar, G. (2004) "BOT Contracts and Modern Development of Concession Contract". Dar el Nahda elmasryia, Cairo.

[10] Ministry of Finance of Slovak Republic, Public private partnership (2005) Finance.gov.sk. Retrieved 7 , [online] http://www.finance.gov.sk/EN/Documents/1_Adresar _redaktorov/Hylova/PPP/PPPPolicy Final.rtf (Accessed 11 September 2020).

[11] Gahnem, M. (2009) Infrastructure Projects by BOT, Alexandria.

[12]Uraía Workshop (2015) Public-Private Partnerships for SMART City Management, Oslo, June.

[13] World Bank (2017), "Benchmarking Public-Private Partnerships Procurement 2017: Assessing Government Capability to Prepare, Procure, and Manage PPPs", pp.14, Washington, DC. [Online] http://documents.worldbank.org/curated/en/46396147 6780341706/ pdf/109245-WP-PPPBenchmarkingPUBLIC.pdf (Accessed 28 March 2020).

[14] Eugene McCann," Governing urbanism: Urban governance studies 1.0, 2.0 and beyond", Urban Studies 2017, Vol. 54(2) 312-326, https://journals.sagepub.com/doi/pdf/10.1177/004209 $\underline{8016670046}$ (Accessed 29 September 2020).

[15] Devas, N., with Amis, P., Beall, J., Grant, U., Mitlin, D., Nunan, F. \& Rakodi, C. (2004). Urban governance, voice and poverty in the developing world. London: Earthscan pp 23

[16] Swyngedouw E (2005) Governance innovation and the citizen: The Janus face of governance beyond-thestate. Urban Studies 42(11): 1991-2006. Vol. 42, No. 
11, 1991- 2006, October 2005

file://C:/Users/hp/Downloads/GovernanceUrbanStud ies.pdf (Accessed 28 August 2020).

[17] THE WO R L D B A N K, " Governance: The World Bank's Experience” May 1994 pp 37 http://documents1.worldbank.org/curated/en/7114714 68765285964/pdf/multiOpage.pdf (Accessed 21 May 2020).

[18] Greenbiz website: https://www.greenbiz.com/article/4-strategiesdriving-change-governance, (Accessed 28 September 2020).

[19] Scholl, H. J. and M. C. Scholl, "Smart Governance: A Roadmap for Research and Practice," in Proceedings of the 9th iConference, M. Kindling and E. Greifeneder, Eds., ed. Berlin, Germany: Illinois Digital Environment for Access to Learning and Scholarship (IDEALS), 2014, pp. 163-176. https://www.ideals.illinois.edu/bitstream/handle/2142 $147408 / 060$ ready.pdf?sequence $=2$ \&isAllowed $=y$ (Accessed 30 September 2020).

[20] Suha AlAwadhi, Hans J Scholl, "Smart Governance: A Cross-case Analysis of Smart City Initiatives". 49th Hawaii International Conference on System Sciences, 2016 IEEE.

[21] Zsuzsanna Tomor, Albert Meijer, Ank Michels \& Stan Geertman, "Smart Governance For Sustainable Cities: Findings from a Systematic Literature Review”, Journal of Urban Technology, Informa UK Limited, trading as Taylor \& Francis Group, 2019, VOL. 26, NO. 4, 3-27 https://doi.org/10.1080/10630732.2019.1651178

[22] A. Ramaswami, A. G. Russell, P. J. Culligan, K. R. Sharma, and E. Kumar, "Metaprinciples for developing smart, sustainable, and healthy cities," Science, vol. 352, no. 6288, pp. 940-943, 2016. file:///C:/Users/hp/Downloads/Ramaswamietal.pdf

[23] B. Cohen, "Urbanization in developing countries: Current trends, future projections, and key challenges for sustainability," Technol. Soc., vol. 28, nos. 1-2, pp. 63-80, 2006. file:///C:/Users/hp/Downloads/1s2.0-S0160791X05000588-main.pdf

[24] J. Dodson, "The 'infrastructure turn' in Australian metropolitan spatial planning," Int. Planning Stud., vol. 14, no. 2, pp. 109-123, 2009. 